\title{
EXPERIMENTAL STUDY AND ANALYSIS OF FLAT BELT CONVEYER SYSTEM WITH DIFFERENT R.P.M.
}

\author{
Priyanka Sharma ${ }^{* 1}$ 网 \\ ${ }^{*}$ Sr. Lecturer, Department of Mechanical Engineering, Government Polytechnic College, Shahdol, \\ 484001, (M.P.), India
}

DOI: https://doi.org/10.29121/ijetmr.v7.i9.2020.787

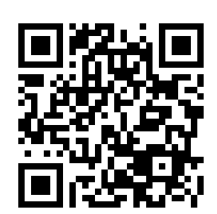

Article Citation: Priyanka Sharma. (2020). EXPERIMENTAL STUDY AND ANALYSIS OF FLAT BELT CONVEYER SYSTEM WITH DIFFERENT R.P.M.. International Journal of Engineering Technologies and Management Research, 7(9), 66-71

https://doi.org/10.29121/ijetmr.v7 i9.2020.787

Published Date: 30 September 2020

Keywords:

Flat Belt

Different R.P.M.

Roller

Load Carrying Capacity

\begin{abstract}
In this paper, we are study about flat belt conveyer system with different R.P.M. such as 50,100,150,200,250 and 300 R.P.M. In this study, it is also included that the observations the different load carrying capacity (Grams) at different working time (Hours). The flat belt conveyer system is very important for the purpose of the material handling system from one place to other place, which is directly depended on the effective length of belt as $1800 \mathrm{~mm}$. In this system we are used the D.C. motor drive system for the purpose of the loading and unloading condition of metallic hook , which is attached the lower portion of flat belt.
\end{abstract}

\section{INTRODUCTION}

The flat belt conveyer system is very useful for material handling system because of it has different speed of Gear head D.C. motor such as 50,100,150,200,250 and 300 R.P.M. The thickness of flat belt has 3.26 mm, width of flat belt has $120.66 \mathrm{~mm}$ and total length of flat belt has $4100.85 \mathrm{~mm}$. The conveyer system is also very important when two units of industries has constructed in different place, in this way material handling drive system is very necessary for the proper working condition of plants.

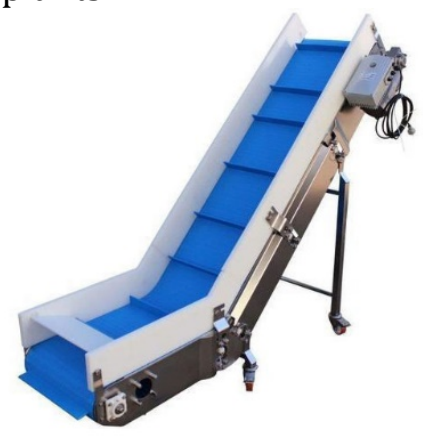

Figure 1: Flat belt conveyer system

(C) 2020 The Author(s). This is an open access article distributed under the terms of the Creative Commons Attribution License, which permits unrestricted use, distribution, and reproduction in any medium, provided the original author and source are credited. 


\section{EXPERIMENT PROCEDURES}

The Gear head Motor, Power supply, Cylindrical Type Roller, Ball bearing (6204ZZ, 6 Piece) and Frame is used the construction of working model and the specification of components are shown in Table.1. In flat belt conveyer system, it is very useful for material handling system one place to other place because of it has different type speed of motor such as 50,100,150,200,250 and 300 R.P.M. with the different load carrying capacity in grams at different working time as 1 to 7 Hours. In this way, First of all load in attached on the hook and D.C. motor has ON condition, when the total working length of flat belt is achieved such as $1800 \mathrm{~mm}$ then motor has OFF condition using of liver based switch during one direction speed of D.C. motor.

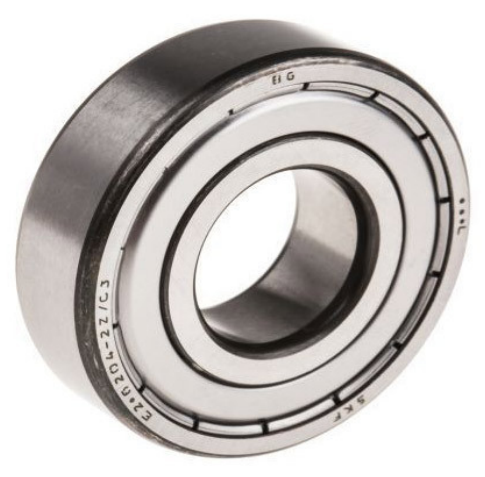

Figure 2: Ball Bearing (6204ZZ)

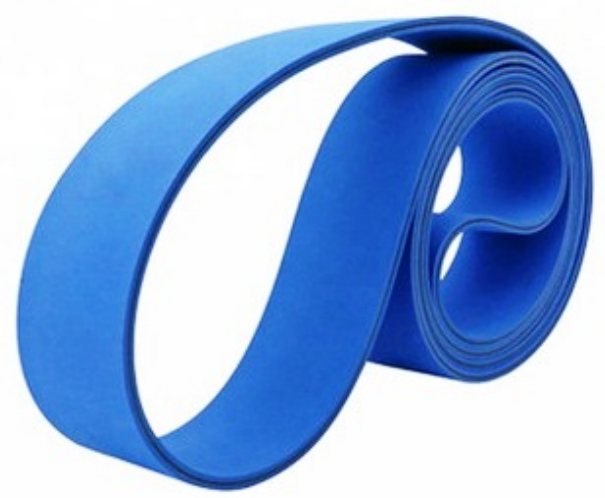

Figure 3: Flat belt

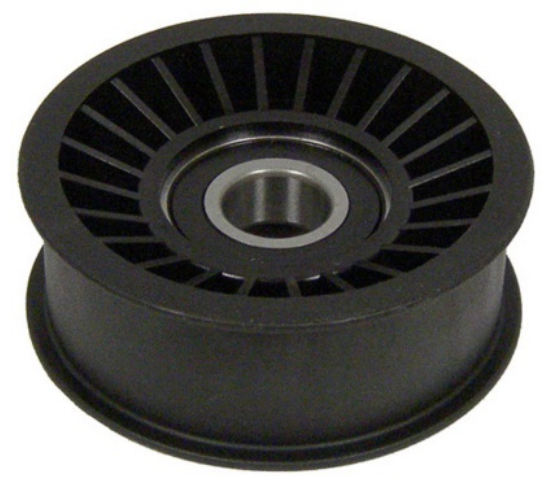

Figure 4: Flat Roller 
Table 1: Specification of components

\begin{tabular}{|c|c|c|}
\hline Sr. No. & Components & Specification \\
\hline 1 & Gear head Motor & 12V.D.C., 10Kgf Torque \\
\hline 2 & Direction of Motor & Both side with Polarity \\
\hline 3 & Power supply & 12V.D.C., Transformer and Rectifier based with 3 Amp. \\
\hline 4 & Roller & Cylindrical Type \\
\hline 5 & Ball Bearing & $6204 Z Z, 6$ Piece \\
\hline 6 & Effective length of belt & 1800 mm \\
\hline 7 & Connection wire & $3 \mathrm{~mm}$ \\
\hline 8 & Frame & Metallic Type \\
\hline
\end{tabular}

\section{RESULTS AND DISCUSSION}

Table 2: Gear head D.C. Motor with 50 R.P.M.

\begin{tabular}{|c|c|c|}
\hline Observation No. & Time (Hours) & Load carrying capacity(Grams) \\
\hline 1 & 1 & 500 \\
\hline 2 & 2 & 1000 \\
\hline 3 & 3 & 1500 \\
\hline 4 & 4 & 2000 \\
\hline 5 & 5 & 2500 \\
\hline 6 & 6 & 3000 \\
\hline 7 & 7 & 3500 \\
\hline
\end{tabular}

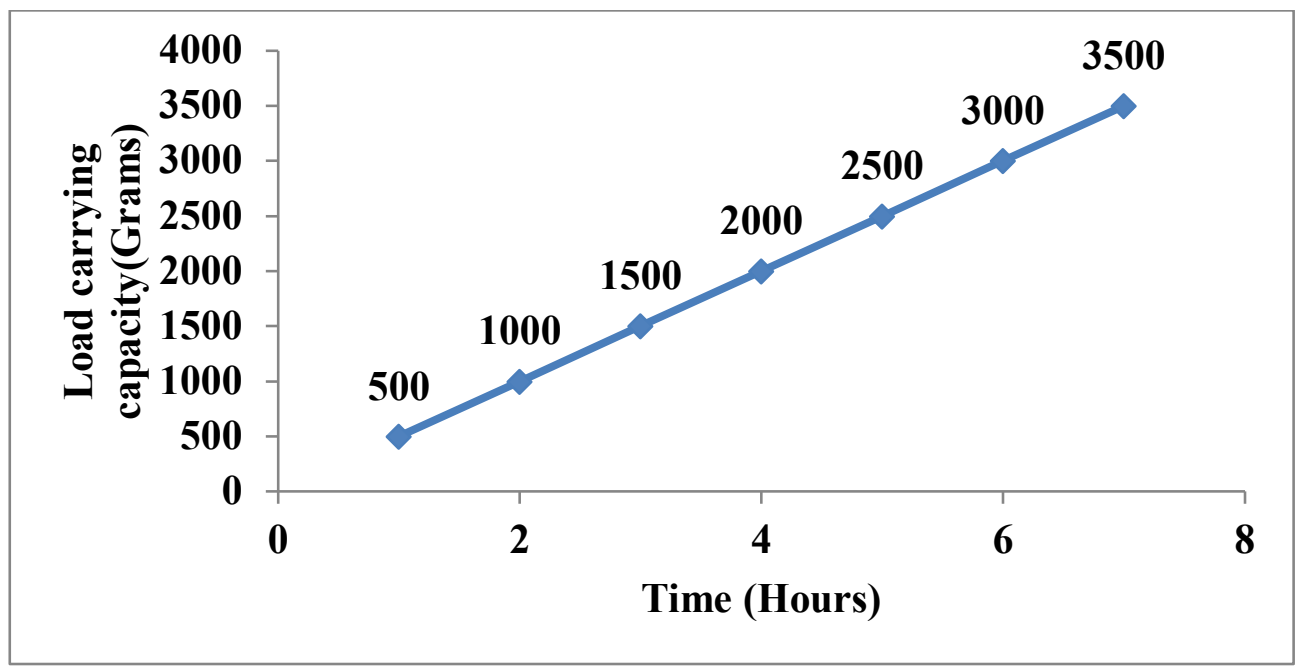

Figure 5: Gear head D.C. Motor with 50 R.P.M.

Table 3: Gear head D.C. Motor with 100 R.P.M.

\begin{tabular}{|c|c|c|}
\hline Observation No. & Time (Hours) & Load carrying capacity(Grams) \\
\hline 1 & 1 & 1000 \\
\hline 2 & 2 & 1500 \\
\hline 3 & 3 & 2000 \\
\hline 4 & 4 & 2500 \\
\hline 5 & 5 & 3000 \\
\hline 6 & 6 & 3500 \\
\hline 7 & 7 & 4000 \\
\hline
\end{tabular}


Experimental Study and Analysis of Flat Belt Conveyer System with Different R.P.M.

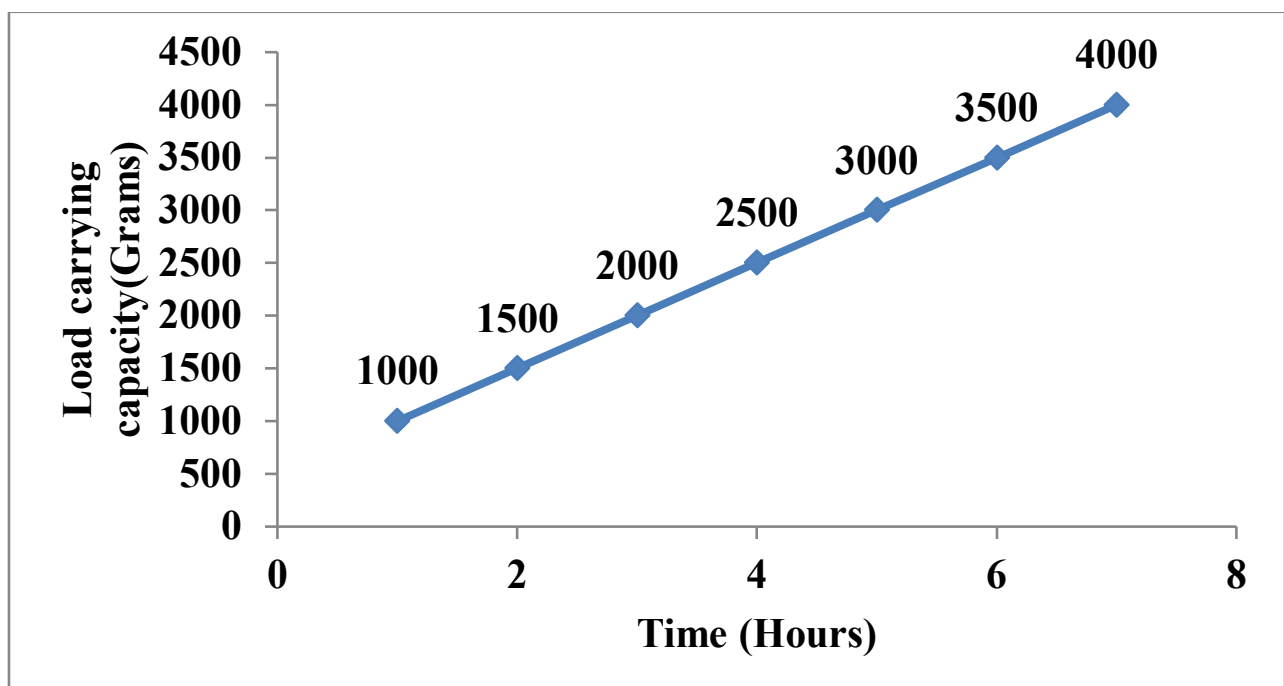

Figure 6: Gear head D.C. Motor with 100 R.P.M.

Table 4: Gear head D.C. Motor with 150 R.P.M.

\begin{tabular}{|c|c|c|}
\hline Observation No. & Time (Hours) & Load carrying capacity (Grams) \\
\hline 1 & 1 & 1500 \\
\hline 2 & 2 & 2000 \\
\hline 3 & 3 & 2500 \\
\hline 4 & 4 & 3000 \\
\hline 5 & 5 & 3500 \\
\hline 6 & 6 & 4000 \\
\hline 7 & 7 & 4500 \\
\hline
\end{tabular}

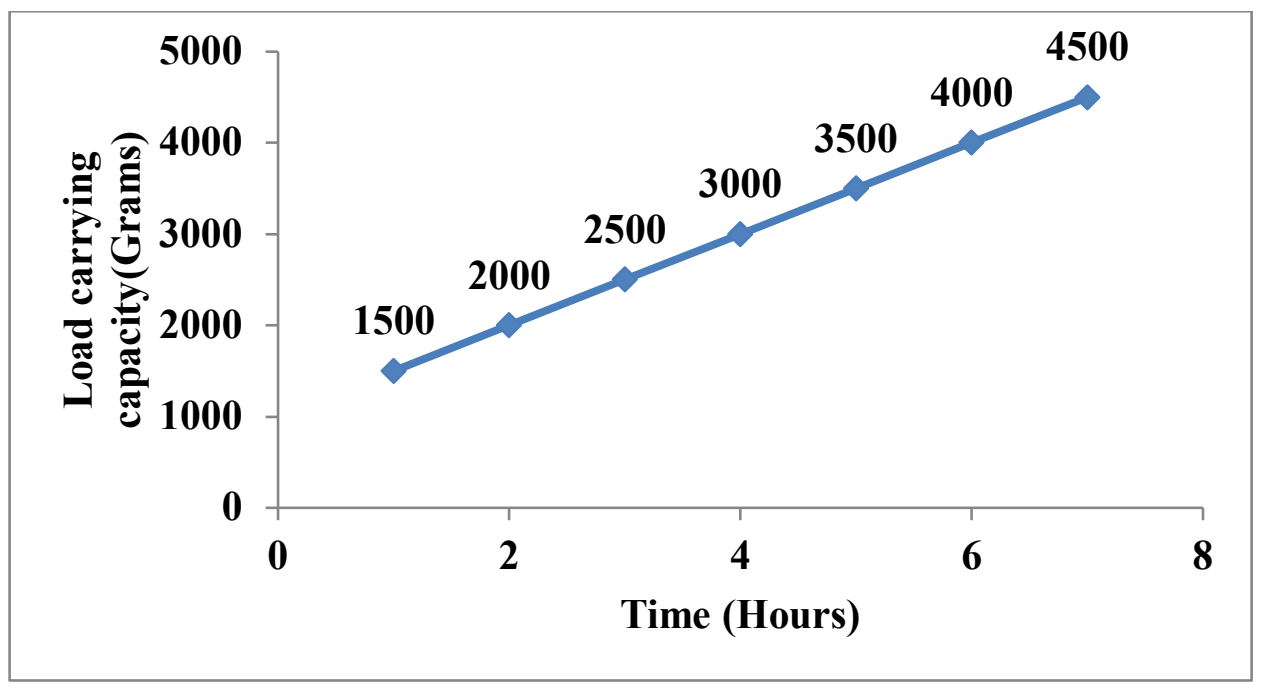

Figure 7: Gear head D.C. Motor with 150 R.P.M.

Table 5: Gear head D.C. Motor with 200 R.P.M.

\begin{tabular}{|c|c|c|}
\hline Observation No. & Time (Hours) & Load carrying capacity (Grams) \\
\hline 1 & 1 & 2000 \\
\hline 2 & 2 & 2500 \\
\hline 3 & 3 & 3000 \\
\hline 4 & 4 & 3500 \\
\hline 5 & 5 & 4000 \\
\hline
\end{tabular}




\begin{tabular}{|l|l|l|}
\hline 6 & 6 & 4500 \\
\hline 7 & 7 & 5500 \\
\hline
\end{tabular}

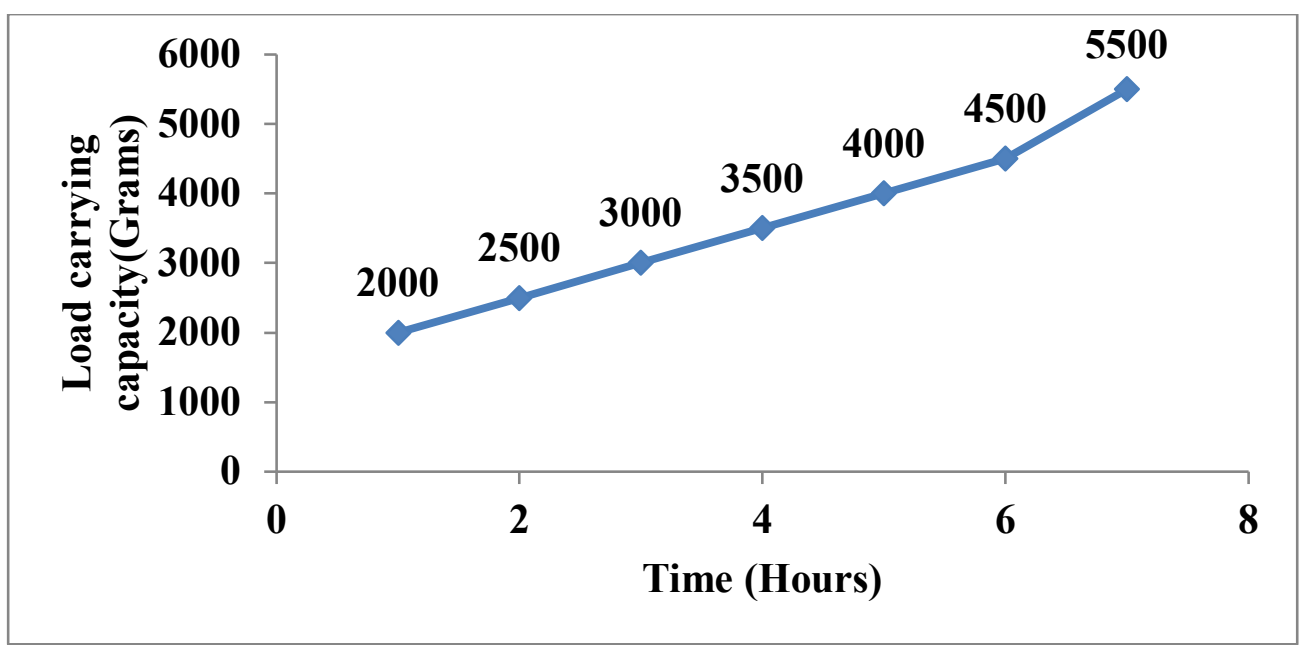

Figure 8: Gear head D.C. Motor with 200 R.P.M.

Table 6: Gear head D.C. Motor with 250 R.P.M.

\begin{tabular}{|c|c|c|}
\hline Observation No. & Time (Hours) & Load carrying capacity (Grams) \\
\hline 1 & 1 & 2500 \\
\hline 2 & 2 & 3000 \\
\hline 3 & 3 & 3500 \\
\hline 4 & 4 & 4000 \\
\hline 5 & 5 & 4500 \\
\hline 6 & 6 & 5500 \\
\hline 7 & 7 & 6600 \\
\hline
\end{tabular}

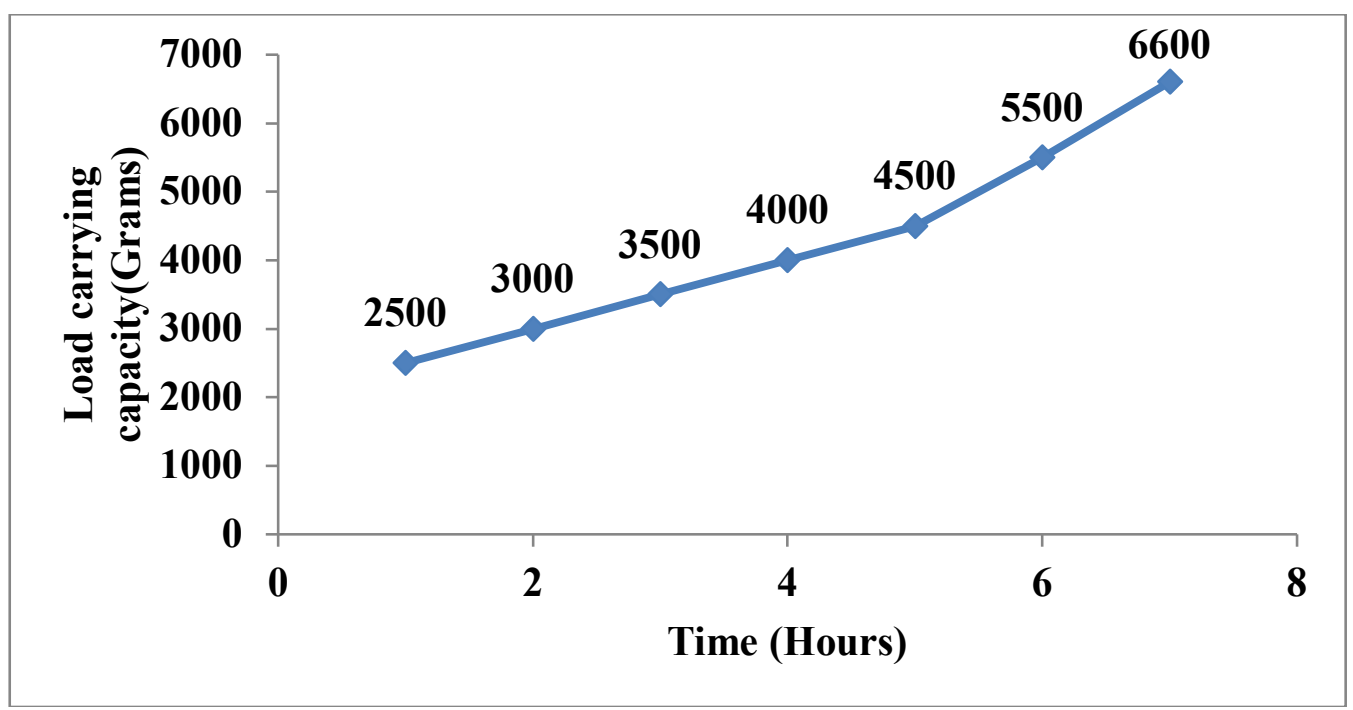

Figure 9: Gear head D.C. Motor with 250 R.P.M.

Table 7: Gear head D.C. Motor with 300 R.P.M.

\begin{tabular}{|c|c|c|}
\hline Observation No. & Time (Hours) & Load carrying capacity(Grams) \\
\hline 1 & 1 & 3500 \\
\hline 2 & 2 & 4000 \\
\hline 3 & 3 & 4500 \\
\hline
\end{tabular}


Experimental Study and Analysis of Flat Belt Conveyer System with Different R.P.M.

\begin{tabular}{|l|l|l|}
\hline 4 & 4 & 5500 \\
\hline 5 & 5 & 6600 \\
\hline 6 & 6 & 6600 \\
\hline 7 & 7 & 6600 \\
\hline
\end{tabular}

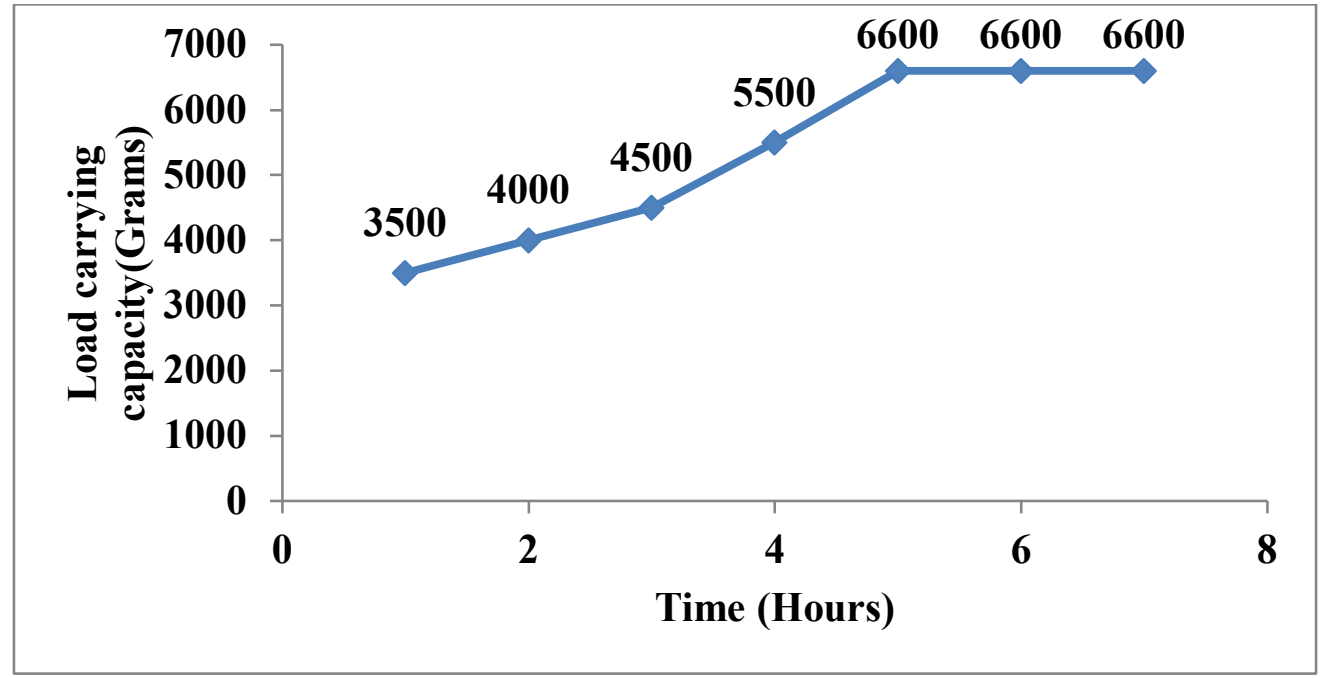

Figure 10: Gear head D.C. Motor with 300 R.P.M.

\section{CONCLUSION}

In this study, we are observed that different load carrying capacity in grams from500 to 6600 grams at different working time in Hours with different R.P.M. such as 50,100,150,200,250 and 300 R.P.M using 12 V. D.C. motor, which has $10 \mathrm{Kgf}$ Torque for proper working condition of flat belt conveyer system. It is found that 6600 grams load which attaches the lower portion of flat belt has constant at the time from 5 to 7 hours of proper working of drive system during speed of Gear head D.C. Motor has 300 R.P.M, which is shown in Table.7.

\section{SOURCES OF FUNDING}

None.

\section{CONFLICT OF INTEREST}

None.

\section{ACKNOWLEDGMENT}

None.

\section{REFERENCES}

[1] R.S. Khurmi S. Chand Textbook of “Machine Design” \& Co. Pvt. Ltd. Edition 2012. ISBN: 81- 219- 2537-1

[2] Bajrić, R., "Recent Advances in Vibration Signal Processing Techniques for Gear Fault Detection-A Review". Applied Mechanic of Materials, 430, 2013, pp.78-83.

[3] Molnár, Vieroslav, et al. "Analysis of asymmetrical effect of tension forces in conveyor belt on the idler roll contact forces in the idler housing." Measurement52 (2014): 22-32.

[4] Li, W., "Design of Online Monitoring and Fault Diagnosis System for Belt Conveyors Based on Wavelet Packet Decomposition and Support Vector N Machine” Advances in Mechanical Engineering, vol. 5, 2013, pp. 1-10. 